\title{
PENYULUHAN MANAGEMENT CREATIVE DALAM MENDONGKRAK INOVASI DAN MEMAJUKAN USAHA PADA SAI SILVER BALI
}

\author{
${ }^{1 *}$ Kharisma Danang Yuangga, ${ }^{2}$ Denok Sunarsi, ${ }^{3}$ Arga Teriyan, ${ }^{4}$ Anak Agung \\ Elik Astari, ${ }^{5}$ Ni Putu Ari Setiawati \\ ${ }^{1.2 .3}$ Universitas Pamulang Tangerang Selatan, Banten, Indonesia \\ ${ }^{4.5}$ Universitas Mahendradatta, Denpasar, Bali, Indonesia \\ Email : *danangyuangga@,gmail.com
}

Manuskrip: Juni -2021; Ditinjau: Juni -2021; Diterima: Juli -2021; Online: Juli-2021; Diterbitkan: Juli-2021

\begin{abstract}
ABSTRAK
Manajemen dalam melaksanakan perannya sangat tergantung kepada seluruh manusia yang terlibat di dalamnya, khususnya bagi para manajer yang berfungsi untuk mengendalikan kreativitas dan digerakkan menuju terciptanya inovasi. Oleh karena itu, kegiatan Pengabdian Kepada Masyarakat ini bertujuan untuk mengetahui dan menjelaskan mengenai inovasi dan kreativitas manusia dalam manajemen dalam mengambangkan usaha kerajianan perak Sai Silver di Bali. Banyak penelitian mengenai manajemen kreatif yang menjadi inspirasi para dosen dalam mengadakan PKM ini, keberhasilan inovasi sangat ditentukan oleh kreativitas manusia, bagi manusia yang tidak kreatif, maka inovasipun sulit dikembangkan, kemudian kebutuhan dan keinginan tidak mungkin dapat diwujudkan sebagaimana diharapkan sebelumnya. Untuk menemukan inovasi melalui kreativitas yang tepat dengan memberikan hasil yang memuaskan semua pihak, disinilah peranan manajemen untuk senantiasa berusaha memadukan antara kreativitas dengan inovasi terhadap suatu bidang kegiatan sehingga dapat menyumbangkan hasil yang dapat memberikan manfaat bagi kehidupan manusia pada umumnya dan manusia yang terdapat dalam manajemen pada khususnya.Kegiatan ini menggunakan media kerajinan perak Sai Silver Bali sebagai media percontohan dalam menyampaikan materi, bagaimana proses penemuan ide, hingga menciptakan terobosan dalam berkarya. Kreativitas dan inovasi dalam dunia industri kerajianan perak sangat dibutuhkan apalagi ditengah konsdisi penuh persaingan. Hasil dari kegiatan ini adalah para para karyawan memiliki kepekaan dan kemampuan untuk selalu mencari terobosan-terobosan dalam bentuk desain yang diaplikasikan dalam produk kerajianan perak yang nantinya akan mereka buat.
\end{abstract}

\section{Kata Kunci: Manajemen Kreativ, Inovasi}




\section{PENDAHULUAN}

Dalam penerapannya manajemen Inovasi merupakan kombinasi dari berbagai pendekatan ilmu manajemen. Gabungan dari proses inovasi dan manajemen perubahan.Manajemen inovasi memungkinkan organisasi untuk menanggapi peluang eksternal atau internal dan menggunakan kreativitas untuk memperkenalkan ide-ide, proses, atau produk. Suatu organisasi agar bisa bersaing dengan organisasi lain maka perlu melalukan inovasi secara terus-menerus dalam berbagai aspek, baik produk, layanan, proses kerja, metode maupun lainnya. Salah satu modal untuk melakukan inovasi adalah adanya kreativitas. Keterkaitan antara keduanya yaitu kreativitas merupakan pengembangan ide-ide baru sedangkan inovasi adalah proses penerapan ide-ide tersebut secara aktual ke dalam praktek. Kreativitas merupakan interaksi antara potensi individu dengan lingkungan. Agar kreativitas berkembang di organisasi maka ada beberapa upaya yang dilakukan yaitu curah pendapat di dalam tim/kelompok kerja, gaya kepemimpinan yang mendorong kreativitas meliputi pengampilan keputusan partisipati, kepemimpinan transformasional, high exchange dan mengmbangkan kultur kreatif Supaya PKM ini tepat sasaran, maka perlu diperhatikan metode pelaksanaan PKM.

PKM ini dilaksanakan pada Kerajinan Perak Sai Silver Bali yang tengah berjuang dalam menghadapi persaingan usaha ditengah pandemi Covid 19 yang memukul telak semua sektor usaha yang ada di Bali.

\section{METODE PELAKSANAAN KEGIATAN}

Adapun metode pelaksanaan PKM ini dilaksanakam beberapa metode yaitu: 1. Metode Ceramah / Presentasi, 2. Metode Tanya Jawa. 3. Sharing Session. Tentang meningkatkan pemahaman para pengerajin perak mengenai inovasi dan kreativitas dalam berkarya. Sharing session ini diberikan kepada para peserta guna mendorong membimbing karyawan yang merupakan pengerajin perak Sai Silver Bali. Adapun hasil dari PKM ini nantinya akan dievaluasi berdasarkan taraf penyelesaian materi pelatihan, dan selanjutnya tim kegiatan PKM akan melakukan evaluasi tersebut dengan mengamati dan memeriksa metode pelaksanaan yang sudah dirancang dan yang telah diberikan kepada karyawan yang perupakan pengerajin perak sebagai peserta.

Metode Pelaksanaan merupakan tahapan-tahapan pelaksanaan yang bersifat teksnis, dalam kegiatan ini metode pelaksanaan berupa memberikan penyuluhan, teknik talkshow, dan pemahaman manajemen dalam menumbuhkan kreativitas dan inovasi dalam meningkatkan pendapatan kerajinan perak Sai Silver Bali .

Tahap pertama: Dosen Pengabdi melakukan observasi awal guna menemukan permasalan dalam warga desa. Setelah ditemukan permasalahan dan solusi, dosen pengabdi mulai melakukan koordinasi dengan mahasiswa dan aparat desa guna mendapatkan ijin penyelenggaraan program Pengabdian Kepada Masyarakat sebagai salah satu kewajiban dosen dalam mengamalkan Tri Dharma Perguruan Tinggi.

Tahap Kedua: Dosen Pengabdi melakukan pembinaan di Balai Warga Desa tentang pentingnya menumbuhkan Kebiasaan Hidup Cermat, Dosen Pengabdi 
menggunakan media Celengan untuk membantu penyampaian materi. Dan mengajak beberapa warga untuk sharing terkait dengan pemahaman mengenamanagemen dan inovasi dalam kerajinan perak.

Tahap Ketiga: Dosen Pengabdi melakukan evaluasi atas kegiatan yang telah dilaksanakan.

Kegiatan diadakan di Sai Silver Bali. Waktu pelaksanaan selama tiga hari, mulai tanggal 2, 3, 4 Maret 2021.

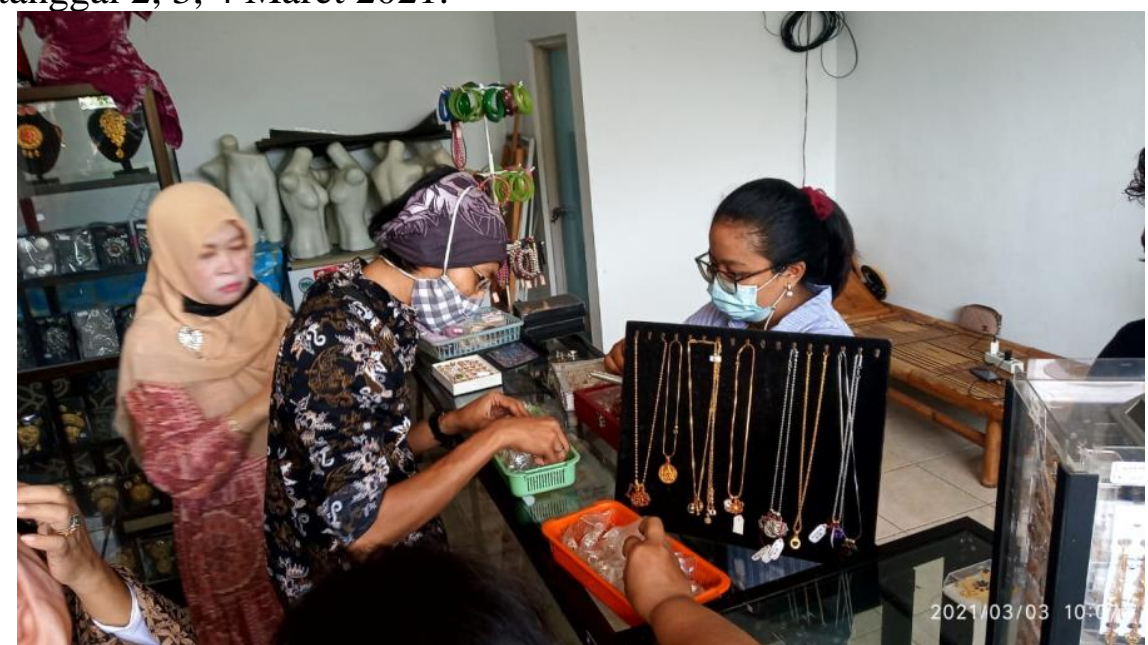

Gambar 1. Foto produk yang dijual

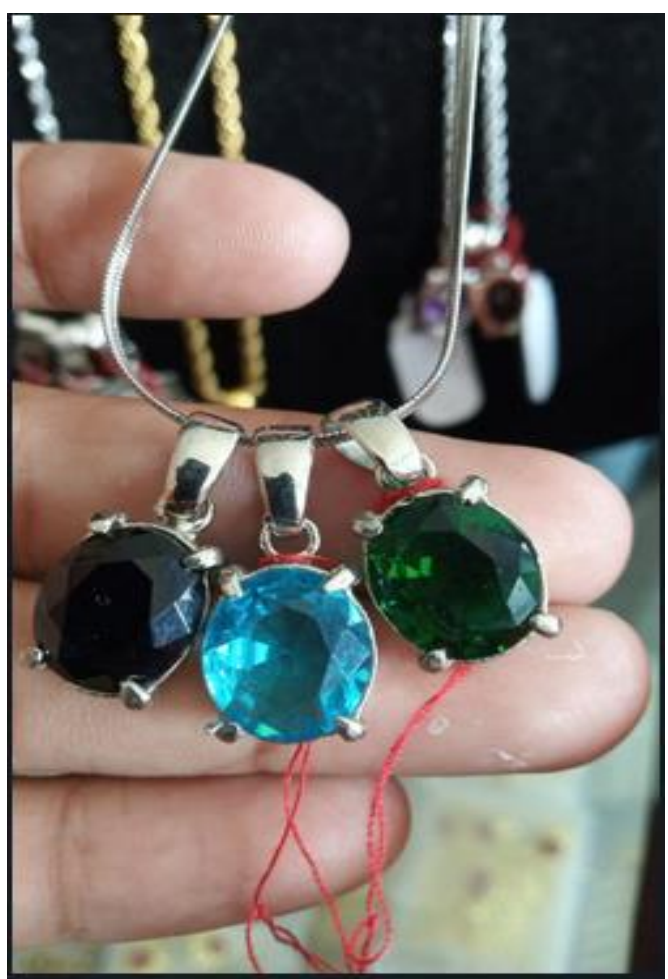

Gambar 2. Foto produk Sai Silver 


\section{HASIL DAN PEMBAHASAN}

Kerajinan perak Bali menjadi salah satu daya tarik wisatawan, Bali sebagai sentral pariwisatanya Indonesia, menawarkan berbagai tempat belanja oleh-oleh, seperti misalnya berbagai hasil kerajinan perhiasan yang terbuat dari emas dan perak, barang kerajinan tersebut dihasilkan dari tangan-tangan trampil di Desa Celuk, Kabupaten Gianyar, begitu bagus dan trampil kwalitas mutu dan seni yang dihasilkan para pengrajin di sini.

Kerajinan perak di Bali yang banyak dihasilkan terkenal tidak hanya dikalangan penduduk lokal atau domestik bahkan sampai ke Macangera, hasil produksi yang dikerjakan oleh warga setempat ini, memang memiliki kualitas unngulan sehingga bisa merambah dunia ekspor.

Hasil kerajinan rumahan atau home industri ini sangat diminati tidak mengherankan banyak artshop yang mudah ditemukan berjejer disepanjang jalan dibeberpa lokasi di pulau Bali. sehingga menjadikan tempat- tempat itu menjadi objek wisata belanja alternatif, karena pada saat wisatawan melakukan tour. Sai Silver Bali merupakan salah satu sentra kerajinan perak yang turut memberikan warna tersendiri bagi kerajinan perak yang ada di Bali.

Pesona perhiasan perak bali memang khas dan memikat sehingga tetap mampu menggugah minat beli pasar. kekhasan itu tak hanya pada keunikan desain dan motif tradisionalnya yang kental nuansa seni budaya bali, perak bali juga tak kalah populer dibandingkan perhiasan emas sebagai koleksi sekaligus sarana investasi. tak salah kalau perak bali makin diminati pasar dalam negeri dan ekspor. menyikapi potensi dan peluang perak bali yang terbuka, sudah tentu tantangan bagi perajin berinovasi juga dalam memarketing produk. hal ini makin vital karena terintegrasi dalam persaingan era digital, perajin dituntut makin peka terhadap setiap perubahan tren mode perak dunia yang tengah berkembang, sehingga mampu menciptakan desain dan motif serta varian produk yang terbaru secara berkesinambungan.

Memarketing produk tak sebatas inovasi desain dan motif saja. di dalamnya menyangkut komitmen menggunakan material bermutu, sehingga hasil produksi sesuai dengan standar perdagangan dunia. selama ini kalau masih banyak perajin perak bali yang mengandalkan bahan baku buatan lokal itu semata karena masih lemahnya kemampuan permodalan dan kurangnya sinergi antarperajin untuk mampu mengakses bahan baku perak yang bermutu dengan kadar 925 persen yang diproduksi pt aneka tambang (antam) jakarta. ke depan ini juga perlu mendapatkan perhatian pemerintah daerah khususnya instansi terkait untuk mampu menyikapi kelemahan para perajin khususnya dalam permodalan selain manajemen bisnis serta promosi dengan begitu daya saing industri perak bali makin bisa diandalkan.

Graham Wallas, dalam bukunya "The Art of Thoughts" menyatakan bahwa sebelum terciptanya sebuah inovasi, ada proses kreatif yang harus dilakukan, yaitu:

\section{Tahap Persiapan}

Ini adalah mempersiapkan diri untuk memecahkan masalah dengan mengumpulkan data atau informasi, mempelajari pola berpikir dari orang lain, dan bertanya pada orang lain. 


\section{Tahap Inkubasi}

Pada tahap ini pengumpulan informasi dihentikan, individu melepaskan diri untuk sementara dari masalah tersebut. Masalah tersebut diendapkan dulu.

\section{Tahap Iluminasi}

Tahap ini merupakan tahap munculnya inspirasi atau gagasan baru.

\section{Tahap Verifikasi}

Ini adalah tahap pengujian ide atau kreasi baru tersebut terhadap realitas. Di sini diperlukan pemikiran yang meliputi proses divergensi (pemikiran kreatif) dan proses konvergensi (pemikiran kritis).

Para pengerajin dituntut untuk terus mengembangkan kreativitas dan berinovasi antara lain untuk:

\section{Meningkatkan Efisiensi Produk}

Inovasi pada sebuah produk bertujuan untuk meningkatkan efisiensinya. Barang yang mengalami inovasi akan dapat melakukan tugasnya dengan tepat sasaran tanpa perlu membuang waktu lebih banyak.

Contohnya pada jasa layanan pengiriman kerajinan perak. Bila dulunya hanya bisa melayani pembelian manual, maka inovasinya bisa dengan memberikan layanan jasa antar/delivery yang didapat dari pesanan online.

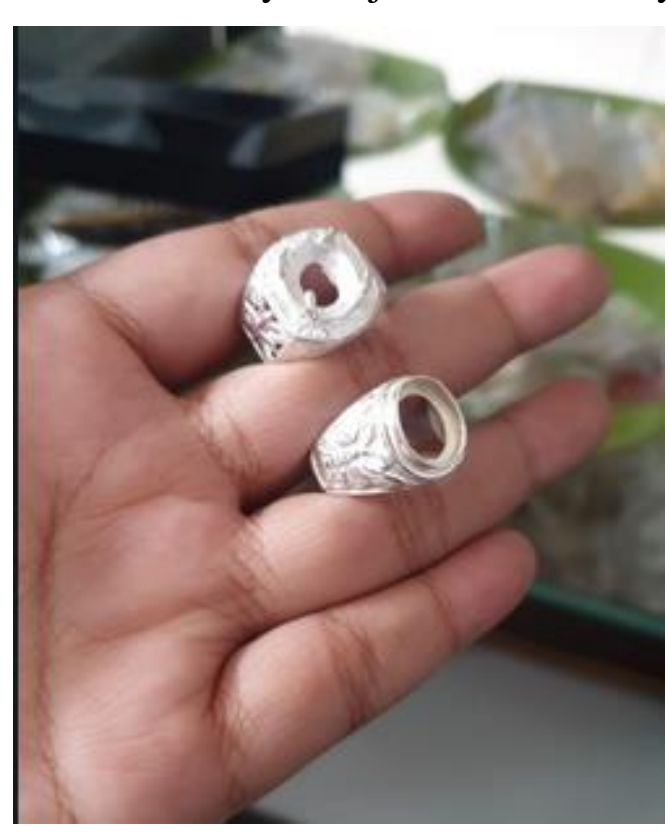

Gambar 3. Bentuk Perak lain

Contoh lainnya, jika dahulu semua transaksi dicatat secara manual, dapat dilakukan transaksi pencatatan sevara online.

\section{Sebagai Pembeda atau Ciri Khas} Bisnis

Salah satu tujuan utama dari inovasi adalah melakukan atau menciptakan sesuatu yang berbeda dari para kompetitor di bidang sama. Besyukur Bali memiliki vibes seni yang sangat kental, sehingga dapat diaplikasikan dengan mudah ke dalam produk-produk yang lekat dengan .ornament etnik ataupun modern. Jika ingin berinovasi pada produk, maka perlu dikembangkan produk itu hingga memiliki keunggulan atau spesifikasi khusus yang tidak ada di pasaran. Dengan begitu, suatu bisnis bisa memiliki pembeda atau ciri khas tersendiri, baik dalam hal produk maupun identitas.

Contohnya produk liontin perak dapat dibongkar pasang menjadi bros atau hiasan rambut. Sehingga dapat menciptakan kegunaan ganda pada satu perhiasan. Atau menambahkan fitur berupa ornament pelengkap agar dapat memiliki berbagai macam looks. 


\section{Menarik Lebih Banyak Konsumen}

Setelah melakukan inovasi dalam bisnis, pengerajin nantinya berpeluang besar untuk menarik banyak konsumen lebih banyak dari sebelumnya. Konsumen memang menyukai hal-hal yang baru dan cenderung lebih unik dan yang memang mereka sukai.

Contohnya pada inovasi produk dapat membuat produk non perhiasan untuk pangsa pasar yang lebih luas, seperti pulpen, pemberat kertas dan tempelan kulkas.

\section{Menciptakan Pasar Baru di Tengah Masyarakat}

Tujuan lain inovasi dalam bisnis adalah untuk menciptakan pasar baru di masyarakat. Produk yang diberi inovasi memberikan fitur dan perkembangan terbaru yang akan menarik minat masyarakat. Sehingga masyarakat tertarik untuk membeli produk tersebut. Inovasi tidak selamanya memberikan perkembangan tetapi kadang juga melakukan pengurangan fitur. Contohnya produk kerajinan perak sebenarnmya dapat ditransformasikan menjadi berbagai macam barang, entah itu aksesori ataupun peralatan sehari-hari. Perlu dilakukan riset yang mendalam yang sejalan dengan visi dan misi usaha dalam berkarya. Pasar yang baru dapat diciptakan dengan membuat lini baru dan terobosan yang berbeda dari biasanya.

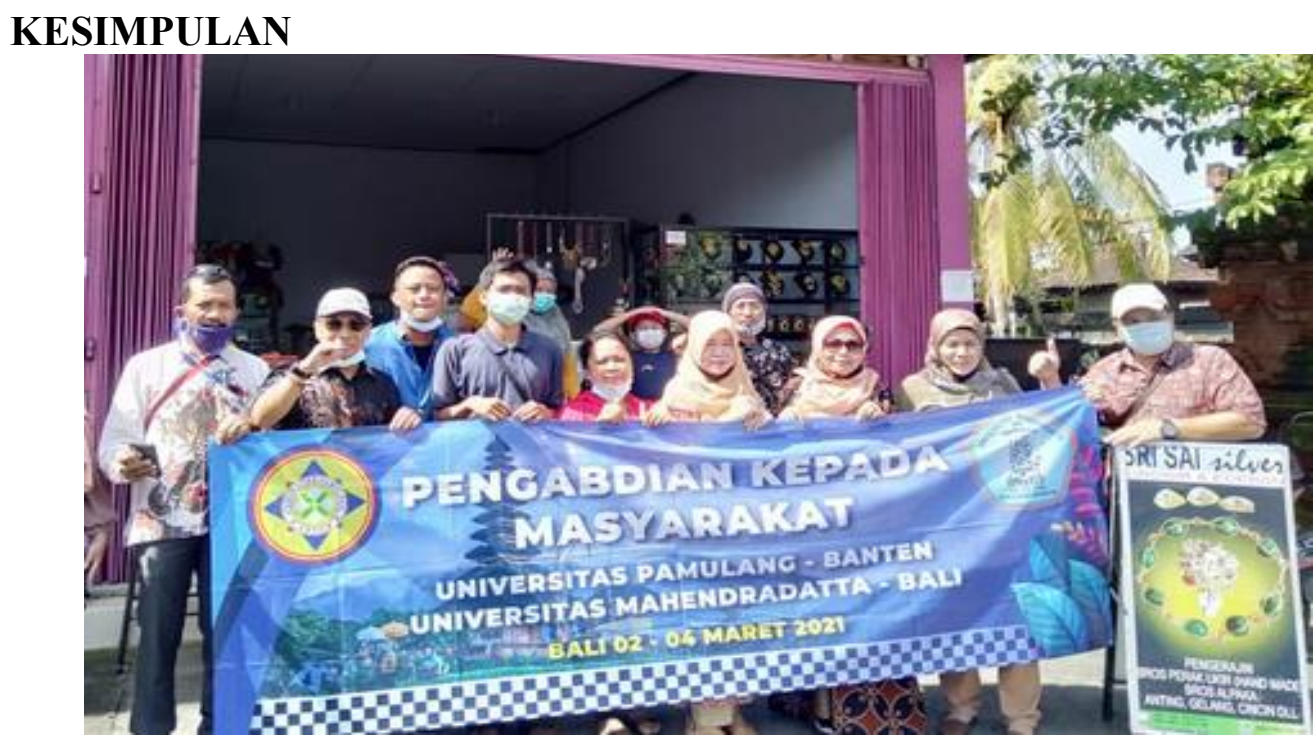

Gambar 4. Foto Bersama kegiatan PKM

Hasil dari kegiatan ini adalah para pengerajin harus mulai kreatif dalam mengembangkan ide untuk produk kerajinan perak, beberapa pengerajin mulai berencana membuat orrnamen baru dalam produk yang akad datang, beberapa juga mulai mencari alternative untuk produk non perhiasan agar dapat mencapai pasar yang berbeda. Inti dari semuanya adalah sebagai pengerajin memang sepatutnya selalu tahu dan paham apa yang sedang terjadi di pasar, agar bisa menentukan kreativitas dan inovasi apa yang cocok untuk kegiatan usaha dalam upaya untuk 
terus mampu memenuhi kebutuhan pasar serta meningkatkan pendapatan disituasi yang serba bersaing.

\section{DAFTAR PUSTAKA}

Affandi, A, et al (2020). Manajemen SDM Strategik. Serang. Bintang Visitama Ajimat, A., et al. (2020). Berwirausaha Memanfaatkan Media Sosial Pada Daerah Sepatan. ADI Pengabdian Kepada Masyarakat, 1(1), 69-76.

Kertamukti, Rama (2015). Strategi Kreatif dalam periklanan. Jakarta: PT Rajagrafindo Persada

Kristianti, L. S., Affandi, A., Nurjaya, N., Sunarsi, D., \& Rozi, A. (2021). Pengaruh Motivasi Dan Disiplin Kerja Terhadap Kinerja Pegawai Pada Dinas Pariwisata Purwakarta. Jurnal Ilmah PERKUSI, 1(1), 101-109.

McQuail, Denis (2011). Teori Komunikasi Massa McQuail, Jakarta: Salemba Humanika.

Nugroho, Sarwo (2015). Manajemen Warna dan Design. Yogyakarta: CV Andi Offset.

Sobur, Alex (2003). Semiotika Komunikasi, Bandung: PT Remaja Rosdakarya.

Tatang (2016). Dinamika Komunikasi, Bandung: Pustaka Setia

Vera, Nawiroh (2015). Semiotika dalam Riset Komunikasi. Bogor: Ghalia Indonesia. 